\title{
FEATURES OF THE LEAN PRODUCTION IMPLEMENTATION AT THE ENTERPRISES OF UKRAINE'S DAIRY INDUSTRY
}

\author{
Mariia Foshchii ${ }^{1}$, Natalia Krasnokutska ${ }^{2}$
}

\begin{abstract}
The purpose of the paper is to study the features of the lean production implementation in the dairy industry of Ukraine. Methodology. To achieve the purpose and solve the tasks set in the paper, a system of general and special research methods was used, namely methods of scientific knowledge (scientific abstraction, analysis and synthesis, deduction, generalization) to study the theoretical principles of the lean production implementation in Ukraine's enterprises, and questionnaire to assess the lean production implementation's effectiveness in the enterprises of Ukraine's dairy industry. Results of the survey examine the theoretical and methodological foundations of the "lean production" concept: taking into account all the definitions mentioned above, the following author's definition of lean production is put forward: lean production is a system of the enterprise, which is constantly improving, aimed at building all processes in a continuous flow of value creation by preventing and eliminating all types of losses, involving staff in teamwork based on project approaches and maintaining safe working conditions in order to create attractive value for the consumer. Methodological support for rapid assessment of the lean production implementation's effectiveness on the basis of employee surveys has been developed and the efficiency of the lean production implementation at the enterprises of Ukraine's dairy industry has been assessed. It is concluded about the lack of effectiveness of implementing lean production at three enterprises of Ukraine's dairy industry. This is due to the short period of the lean production implementation, as Enterprise 1 only started implementation at the end of 2020. Based on the survey and questionnaire of employees and managers of Ukraine's dairy industry, the main stereotypes related to the implementation of lean production are identified and refuted, and the reasons for the slow and inefficient implementation of lean production are identified. Lean manufacturing cannot be implemented once and for all, it must be done constantly, because lean manufacturing is a tool for gaining a competitive advantage. Scientific novelty: methodological support for rapid assessment of the lean production implementation's effectiveness has been further developed, which, unlike others, takes into account the peculiarities of the dairy industry and allows to determine problems and prospects for enterprise development on the basis of a questionnaire. A promising direction of research is a more detailed analysis of the "lean production polygon", which is based on the survey. A more detailed analysis of the underlying three pentagons will reveal problems in the three subsystems of lean production.
\end{abstract}

Key words: lean production, concept, implementation of lean production, efficiency assessment, problems of the lean production implementation.

JEL Classification: M10, L23, O10, O39

\section{Introduction}

In modern constant changes of market conditions, many companies seek to increase the efficiency of their activities through various tools and methods of organizing production. One of the most popular and effective methods currently implemented in the practice of economic entities is lean production.

Corresponding author:

${ }^{1}$ National Technical University “Kharkiv Polytechnic Institute”, Ukraine.

E-mail: mfoschiy1994@gmail.com

ORCID: https://orcid.org/0000-0003-1555-3110

${ }^{2}$ National Technical University "Kharkiv Polytechnic Institute”, Ukraine.

E-mail: krasnokutskaya.natalia@gmail.com

ORCID: https://orcid.org/0000-0001-8184-3816

ResearcherID: J-4698-2018
Many Ukrainian companies, against the Japanese and Western companies, have recently begun to apply this concept; at the same time, they have already formed and continue to develop their systems.

Despite the fact that the founders of lean production are exclusively foreign scientists, in Ukraine studies have also been conducted in close contact with the provisions 
of this concept. These are the works of such scientists as Omelianenko T. V., Shcherbyna O. V., Barabas D. O., Vakulenko A. V. (2009), Kobyliuk O. Ya., Melnyk H. M. (2012), Kolos I. V. (2017), Kharchenko H. A., Kharchenko V. V. (2021). Scientific works and developments of the mentioned authors have made a significant contribution to the study of various problems of lean production in enterprises. At the same time, most of the topical issues related to the implementation of lean production in Ukrainian enterprises have not yet received a sufficiently comprehensive, systematic coverage and appropriate scientific explanation in the literature.

The purpose of the paper is to study the features of the lean production implementation in the dairy industry of Ukraine. To achieve this goal, the following tasks were performed: the theoretical and methodological foundations of the "lean production" conceptare studied; the methodological support for rapid assessment of the lean production implementation's effectiveness on the basis of employee surveys are developed; the efficiency of the lean production implementation at the enterprises of Ukraine's dairy industry is estimated; on the basis of the conducted survey and questionnaire of workers and heads of Ukraine's dairy industry enterprises the basic stereotypes which are connected with implementation of lean production are allocated and refuted; on the basis of the whole research the reasons of slow and inefficient implementation of lean production at the enterprises of Ukraine's dairy industry are revealed.

To achieve the purpose and solve the tasks set in the paper, it was used a system of general and special research methods: methods of scientific knowledge (scientific abstraction, analysis and synthesis, deduction, generalization) to study the theoretical principles of the lean production implementation in Ukraine's enterprises, and questionnaire to assess the lean production implementation's effectiveness in the enterprises of Ukraine's dairy industry.

\section{Theoretical and methodological foundations of the "lean production" concept}

The study of lean production's implementation peculiarities will begin with an analysis of the concept. The phenomenon of lean production originated in Japan, whose companies in the mid-50s formed a special approach to the organization of production processes and later other processes, which allowed a country that has virtually no natural resources, to take second place in the world in terms of GDP. The system is gaining more and more recognition in the world when US industrialists have felt fierce competition from the Japanese in their own car market.

The term "Lean Production", or "Lean Manufacturing", was firstly used in the mid-1980s by production organization specialist John Krafcik in a comparative study of Japanese and American automobile companies (Krafcik, 1988). The term "Lean Production" summarizes the production system of "Toyota" company, the main elements of which were developed over 26 years (from 1947 to 1973) by specialists such as Ohno Taiichi (Taiichi, 2012) and Shigeo Shingo (Shingo, 2010). Today, the term "Lean" is interpreted differently by some authors.

In our opinion, in the scientific literature today, there is no most complete and clear formulation and definition of the "lean production" concept. Some authors try to present "lean production" as a management concept, opposed to mass production, the essence of which is to accelerate production processes by reducing seven types of losses that do not add value to the product (Taiichi, 2012; Vumek et al., 2007), others try to present it as philosophy management, focused on the continuous development of the organization employees (Shingo, 2010; Krige, 2012). A number of "lean production" definitions, which are found in the works of many authoritative foreign and domestic scientists, were studied, and therefore we can say that nowadays the first approach prevails in the literature.

Lean production is one of the most relevant and effective management models, aimed at streamlining the production process by steadily eliminating all types of losses and involving each employee in the process of optimizing the business. The significance of this concept is determined by such important laws of capitalist production as the desire for a steady increase in profits and growing competition, which require not only continuous improvement of products (services) and technological systems but also constant work to reduce the costs of production and commercial activity in enterprises. However, in management science uncertain and one-sided vision of this concept continues to remain, which is well traced in the evolution of ideas about lean production.

Thus, in this study, taking into account all the definitions mentioned above, the following author's definition of lean production is put forward: lean production is a system of the enterprise, which is constantly improving, aimed at building all processes in a continuous flow of value creation by preventing and eliminating all types of losses, involving staff in teamwork based on project approaches and maintaining safe working conditions in order to create attractive value for the consumer.

\section{Evaluating the effectiveness of implementing lean production}

To assess the effectiveness of the enterprise in the implementation of lean production, scientists (Kovaleva et al., 2013) propose to use the "wheel of lean production". The wheel of lean production includes a strategic triangle, intellectual triangle, and 
industrial triangle (Kovaleva et al., 2013). Each of these triangles shows the problems and opportunities for the development of lean production in relevant areas. Similar to a wheel, it is possible to offer the use of a lean production polygon. The polygon is based on three pentagons in three subsystems of lean production.

Figure 1 shows the methodological support for rapid assessment of the lean production implementation's effectiveness, which, unlike others, takes into account the peculiarities of the dairy industry and allows to identify problems and prospects for enterprise development on the basis of questionnaires.

On the basis of the developed methodological support, the estimation of the lean production implementation's effectiveness at three enterprises of Ukraine's dairy industry is carried out.

According to stage 1 (Formation of an expert group to conduct a survey), expert groups of 20 people were formed at each of the three enterprises. The expert groups included both managers and employees of the production shops of Ukraine's dairy industry.

According to the stage 2 of the developed methodological support, a questionnaire was conducted on the basis of 45 questions. To answer the question, the experts gave scores in points from 0 to 3 : where 0 is the complete absence of a sign in the enterprise; 1 point score for extremely low level, no result; 2 points - there is an assessment for the available positive results, but there are reserves for revitalization; 3 points - an assessment for the highest level of results, continuous improvement of the enterprise in this direction.
As a result of the survey among the expert groups formed at three enterprises of Ukraine's dairy industry, 60 questionnaires with answers to 45 questions were received. According to the stage 3 of the developed methodological support, the results of the survey were processed and systematized. To do this, 45 questions were divided by 3 between 15 indicators. So, the average score is determined using the arithmetic mean for 15 indicators in three subsystems of lean production.

The maximum number of points for each component is 9 points. Based on the systematized results of the survey, in Figure 2 a "lean production polygon" was constructed.

To systematize the evaluation results, they are summarized in three subsystems of lean production:

1. Subsystem "Management": availability of strategic management; the presence of a lean production philosophy; declaration and principles of the lean production; use of key performance indicators (KPIs), involvement of top management in the implementation of lean production.

2. Subsystem "Business Processes": the presence of $5 \mathrm{C}$; work with suppliers and dealers; study of customer's requirements and satisfaction; cost reduction; product quality management.

3. Subsystem "Staff": the effectiveness of employee training; cohesion of employees; education of leaders who profess the philosophy of lean production; availability and quality of Kaizen-proposals; use of labor division.

Stage 1. Formation of an expert group to conduct a survey

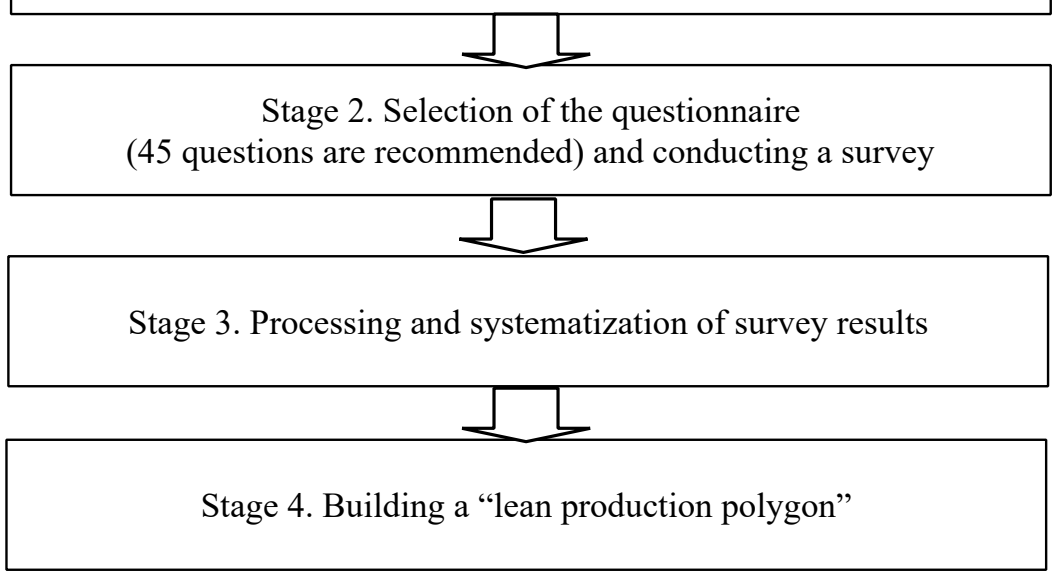

Stage 5. Identification of problematic and promising directions for enterprise development

Figure 1. Methodological support for rapid assessment of the lean production implementation's effectiveness on the basis of employee surveys

Source: developed by the authors 


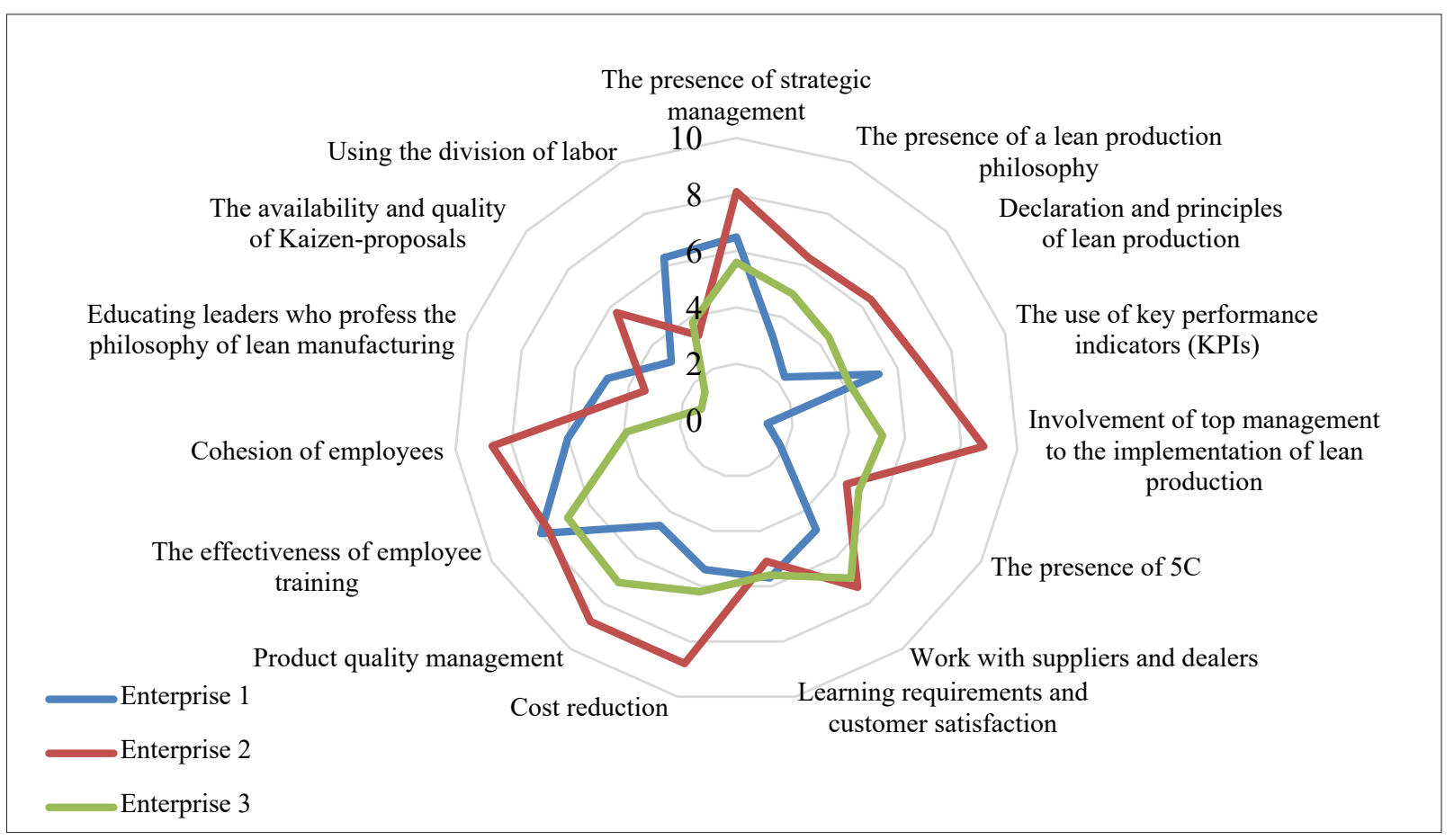

Figure 2. "Lean production polygon" based on a survey for three enterprises of Ukraine's dairy industry

Source: developed by the authors

According to Figure 2, we can conclude about the lack of effectiveness of implementing lean production at three enterprises of Ukraine's dairy industry. This is due to the short period of the lean production implementation, as Enterprise 1 only started implementation at the end of 2020. At the next stage of the research the main problems of the lean production implementation at the enterprises of Ukraine's dairy industry are defined.

\section{Stereotypes associated with the implementation of lean production}

Ukrainian companies often try to implement lean production in at least a few months, up to a year. Even with a positive attitude, the interest of senior management, minimal staff resistance, companies come to a standstill in the implementation of lean production. Some of the problems are related to the existing stereotypes about the implementation of lean production.

Based on questionnaires and surveys of employees and managers in Ukrainian dairy companies, the main stereotypes related to the implementation of lean production are identified. There are many definitions of a stereotype. The most common definition of stereotype is the following (Chekanova, 2017): a stereotype is a schematic, standardized image or representation that expresses a person's habitual attitude to a phenomenon that has developed under the influence of social conditions and previous experience.
The main stereotypes associated with the implementation of lean production in the dairy industry of Ukraine:

1. The implementation of lean production is always quick, easy and simple, so the effective result will be noticeable immediately.

2. The implementation of lean production does not require additional costs.

3. Lean production is a universal method that will solve the main problems in the enterprise.

4. Lean production is the right inventory management policy by reducing inventory.

5. The implementation of lean production means mandatory job cuts.

Let us refute the above stereotypes, which were obtained on the basis of questionnaires and surveys of employees and managers in Ukrainian dairy companies: 1. The implementation of lean production is not always quick, easy, and simple. The implementation of lean production often requires many attempts. Ten or more options for optimizing the planning of the shop - it is a little. Even more attempts to build a value chain are also few. Just bringing all the requirements to each employee requires a lot of time and may cause complications. Therefore, the effective result from the implementation of lean production will not be noticeable immediately.

2. The implementation of lean production does not require additional costs. Costs are required for both staff training and the actual implementation of lean 
production methods. However, if methods are properly implemented, all costs are quickly reimbursed.

3. Lean production is just one of the powerful management tools that work in conjunction with others. Lean production is not a universal method that will solve the main problems in the enterprise. It is a tool to increase the competitiveness of the enterprise, which is needed to make products faster than competitors, cheaper than competitors, and better than competitors.

4. Inventory reduction is not yet lean production, it is just one of the tools to reduce losses and increase processes efficiency. Reduce inventories is not a problem, the problem is to reduce inventories so as to maintain the stability and rhythm of production and even improve compliance with the requirements of all consumers throughout the product range.

5. The implementation of lean production is not a reduction, but a redistribution of resources. At any enterprise there is an uneven distribution: someone is loaded (or even overloaded), someone is underloaded. Well, as for staff reductions, it is true that European companies sometimes also reduce staff. The Japanese have a completely different approach. Continuous improvement requires resources, so if "free" workers appear, they are included in the improvement process. This is how the "chain reaction of quality" is started.

Thus, the stereotypes identified on the basis of questionnaires and surveys of employees and managers in Ukrainian dairy companies were refuted. However, on the basis of these stereotypes, as well as other results of questionnaires and surveys, it was possible to identify the reasons for the slow and inefficient implementation of lean production in the dairy industry of Ukraine.

\section{Reasons for slow and inefficient implementation of lean production}

According to the authors, the reasons for the slow and inefficient implementation of lean production in the dairy industry of Ukraine:

Reason 1. Misunderstanding of the concept of lean production and the presence of stereotypes about the implementation of lean production. Moreover, misunderstanding is inherent in both managers and employees who directly produce products.

Reason 2. Lack of understanding or disregard mandatory stages of implementing lean production. Often companies enthusiastically implement lean production without understanding the passage of mandatory stages of implementation. Mandatory tasks are the obligatory stages for the implementation (definition of value, definition of a value chain, the organization of a chain movement, extraction of a product, perfection, inclusion of workers in activity and granting powers to them).

Reason 3. Fuzzy understanding of the lean production goals. It is necessary to choose a pilot area, determine the value from the consumer's perspective, describe the situation as it is, develop a program to reduce all types of losses and increase the efficiency of processes, systematically reduce losses.

Reason 4. Due to the misunderstanding of the concept, philosophy, and goals of lean production, there is a misunderstanding of the need to systematize lean production tools and the stages of their implementation in the enterprise. The most important thing is to understand very clearly what tools of lean production and in what sequence you need to implement and apply "step by step". Without this understanding, the implementation of lean manufacturing will turn into an obstacle course.

Reason 5. Misunderstanding of the lean production relationship with other methods. If there is an understanding of the relationship between lean production tools and the quality management system (QMS), the synergy will achieve significant results with minimal effort. However, often in the enterprises of the dairy industry in Ukraine, quality management and implementation of lean production are two separate projects implemented by two independent structures, spending twice as much effort.

Lean production cannot be implemented once and for all, it must be done constantly, because lean production is a tool for gaining competitive advantage.

\section{Conclusions}

Thepaperexaminesthetheoreticalandmethodological foundations of the "lean production" concept: taking into account all the definitions mentioned above, the following author's definition of lean production is put forward: lean production is a system of the enterprise, which is constantly improving, aimed at building all processes in a continuous flow of value creation by preventing and eliminating all types of losses, involving staff in teamwork based on project approaches and maintaining safe working conditions in order to create attractive value for the consumer.

Methodological support for rapid assessment of the lean production implementation's effectiveness on the basis of employee surveys has been developed and the efficiency of the lean production implementation at the enterprises of Ukraine's dairy industry has been assessed. It is concluded about the lack of effectiveness of implementing lean production at three enterprises of Ukraine's dairy industry. This is due to the short period of the lean production implementation, as Enterprise 1 only started implementation at the end of 2020.

Based on the survey and questionnaire of employees and managers of Ukraine's dairy industry, the main stereotypes related to the implementation of lean production are identified and refuted, and the reasons for the slow and inefficient implementation of lean 
production are identified. Lean manufacturing cannot be implemented once and for all, it must be done constantly, because lean manufacturing is a tool for gaining a competitive advantage.

Scientific novelty: methodological support for rapid assessment of the lean production implementation's effectiveness has been further developed, which, unlike others, takes into account the peculiarities of the dairy industry and allows to determine problems and prospects for enterprise development on the basis of the survey.

A promising direction of research is a more detailed analysis of the "lean production polygon", which is based on the survey. A more detailed analysis of the underlying three pentagons will reveal problems in the three subsystems of lean production.

\section{References:}

Chekanova, S. A. (2017). Rol stereotipov v mezhkulturnom obshchenii [The role of stereotypes in crosscultural communication]. Sovremennaya nauka: aktual'nye problemy teorii i praktiki, no. 12, pp. 263-265.

Honcharuk, O. V., Hubarenko, L. M., \& Tsupryk, L. M. (2019). Teoretyko-metodychni osnovy systemy berezhlyvoho vyrobnytstva na pidpryiemstvi [Theoretical and methodical bases of the system of lean production at the enterprise]. Skhidna Yevropa: ekonomika, biznes ta upravlinnia [Eastern Europe: Economy, Business and Management.] (electronic journal), vol. 1, no. 18, pp. 95-103. Available at: http://www.easterneurope-ebm.in.ua/ journal/18_2019/18_2019.pdf (accessed 10 June 2021).

Kharchenko, H.A., \& Kharchenko, V.V. (2021).Vprovadzhennia berezhlyvoho vyrobnytstva v silskohospodarskykh pidpryiemstvakh yaknapriam pokrashchennia yikh konkurentospromozhnosti[Introduction of sleepful production in agricultural enterprises as a direction of improving their competitiveness]. Proceedings of the II Mizhnarodna naukovo-praktychna konferentsiia «Biznes, innovatsii, menedzhment: problemy ta perspektyvy» (Ukraine, Kyiv, April 22, 2021), Kyiv: Igor Sikorsky Kyiv Polytechnic Institute, Publ. house «Politekhnika», pp. 240-241.

Kobyliuk, O. Ya., \& Melnyk, H. M. (2012). Oshchadlyve vyrobnytstvo yak kontseptsiia optymizatsii vyrobnychoho ta upravlinskoho protsesiv [Lean production as a concept of optimization of production and management processes]. Visnyk Natsionalnoho universytetu "Lvivska politekhnika" [Bulletin of the National University "Lviv Polytechnic"], no. 749, pp. 43-49. Available at: http://ena.lp.edu.ua/bitstream/ntb/23489/1/10-43-49.pdf (accessed 10 June 2021).

Kolos, I. V. (2017). Typolohiia metodiv oshchadlyvoho vyrobnytstva [Typology of lean production methods.] Skhidna Jevropa: ekonomika, biznesta upravlinnia [Eastern Europe: Economy, Business and Management.] (electronic journal), vol. 3, no. 8, pp. 147-152. Available at: http://www.easterneurope-ebm.in.ua/journal/8_2017/28.pdf (accessed 10 June 2021).

Kovaleva, S. A., \& Bazarnova, O. A. (2013). Berezhlivoe proizvodstvo kak faktor povysheniya konkurentnosposobnosti predpriyatiya [Lean manufactiring as a factor of company's competitiveness improvement]. Region: sistemy, ekonomika, upravlenie, vol. 3, no. 22, pp. 62-65.

Krafcik John (1988). Triumph of the Lean Production System. Sloan Management Review, no. 41, pp. 41-52.

Kriger, A. A. (2012). Povyshenie effektivnosti upravleniya promyshlennymi predpriyatiyami $v$ Rossii na osnove kontseptsii "berezhlivogo" proizvodstva [Improving the management efficiency of industrial enterprises in Russia based on the concept of "lean" production]. (Avtoref. diss. na soiskanie uchenoy stepeni kand. ekon. nauk). Moscow: Tsentr. ekonom.-mat. in-t RAN, p. 22. (in Russian)

Omelianenko, T. V., Shcherbyna, O. V., Barabas, D. O., \& Vakulenko, A. V. (2009). Oshchadlyve vyrobnytstvo: konceptsiia, instrumenty, dosvid [Lean production: concept, tools, experience]. Kyiv: KNEU, Naukovo-praktychne vydannia, p. 157. (in Ukrainian)

Shingo Shigeo (2010). Izuchenie proizvodstvennoy sistemy Toyoty s tochki zreniya organizatsii proizvodstva [Study of the Toyota production system from the point of view of the organization of production]. Moscow: Institut kompleksnykh strategicheskikh issledovaniy, p. 312. (in Russian)

Taiichi Ohno (2012). Proizvodstvennaya sistema Toyoty. Ukhodya ot massovogo proizvodstva [Toyota production system. Moving away from mass production]. Moscow: Institut kompleksnykh strategicheskikh issledovaniy, p. 208. (in Russian)

Womack, J., Jones, D., \& Roos, D. (2007). Mashina, kotoraya izmenila mir [The machine that changed the world]. Moscow: Popurri, p. 384. (in Russian) 